\title{
sciendo
}

\section{Possibilities of statistical analysis of hotel activity performance in a competitive environment}

\author{
Simona-Ioana GHIT, $\breve{A}$ \\ The Bucharest University of Economic Studies, Bucharest, Romania \\ Institute of National Economy, Bucharest, Romania \\ simona.ghita@csie.ase.ro \\ Rodica-Manuela GOGONEA \\ The Bucharest University of Economic Studies, Bucharest, Romania \\ manuela.gogonea@gmail.com \\ Simona-Andreea SĂSEANU \\ The Bucharest University of Economic Studies, Bucharest, Romania \\ andreea.saseanu@com.ase.ro
}

\begin{abstract}
The hotel industry is an important driver in tourism development of a region, with positive effects on economic growth, concentrating to a large extent the regional tourism services. The quality of services in this sector is decisive for improving the hotel activity performance, especially in terms of a competitive environment increasingly well defined. The service quality is directly proportional to the hotel comfort category. In 2018 Romania had 34 five-star hotels and 359 four-star hotels, representing less than a quarter of all hotels (24.32\%). They owned just over $30 \%$ of the total number of hotel bedplaces. This paper provides a statistical analysis of activity in the hotel industry in Romania, focusing on main elements of its performance, in terms of a competitive environment. As a result of a case-study on the employees of high comfort category hotels in Bucharest, the key elements of a performing activity are revealed, in order to obtain a competitive advantage.
\end{abstract}

Keywords: hotel industry, high comfort category hotels, activity performance, competitive advantage, logit ordinal regression model.

\section{Introduction}

The hotel industry is an important driver in tourism development of a region, concentrating to a large extent the regional tourism services and having a positive impact on the community, contributing to its economic, social and cultural welfare. One of the most important factors which can influence to a great extent the hotel activity results is creating and using the competitive advantage.

Tourism is not defined in unique terms, its definitions often vary from one country to another or from one organization to another. Thus, UNWTO defined "Tourism" as: "Tourism comprises the activities of persons traveling to and staying in places outside their usual environment for not more than one consecutive year for leisure, business and other purposes. "(World Tourism Organization - Conceptual definition). According to the definition provided by World Trade Organization, "Tourism and travel-related services includes services provided by hotels and restaurants (including catering), travel agencies and tour operator 
services, tourist guide services and other related services." In the last few decades, specialists' research in the field is increasingly converging towards sustainable tourism, a form of tourism that ensures the optimal use of environmental resources, respect for the sociocultural authenticity of local communities, on the long-term sustainability and profitability of all economic operations - principles that can be applied to all types of tourist destinations. In statistical research, reference is often made to NACE Rev. 2 classification "Hotels and similar accommodation", which includes "the provision of accommodation, typically on a daily or weekly basis, principally for short stays by visitors" (EUROSTAT. Statistics explained). Hotels, resort hotels, suite/apartment hotels and motels are included in this group.

\section{Literature review}

As in any other activity sector, in the hospitality sector as well, the issue of competitiveness and its quantification is a basic element in the hotels activity, in their attempt to increase the satisfaction of their clients. The customers' top preference is the service quality. A highly competitive hotel business has a positive impact on the community, contributing to its economic, social and cultural welfare. (Go, Pine \& Yu, 1994).

Specialized studies have identified several ways and means of measuring the performance of the hospitality industry activity, with their particularity depending on the specificity of the hotel sector.

Thus, as specific aspects of the hotel industry activity, the fierce competition between hotels and the flexibility, the high degree of variation in the circumstances in wich they take place - can be mentioned (Mitrović et al, 2016).

Some authors emphasized the increasing importance of intangible resources in hotel performance measurement process (Zigan \& Zeglat, 2010). Atkinson (2006) shows that an effective assessment of hotel performance should take into account both financial and nonfinancial measures. Success in measuring hotel business performance can be ensured by identifying its critical factors (Atkinson \& Brander Brown, 2001) and by raising the concern and awareness of hotel managers about the benefits of measuring the hotel business performance (Mitrović et al., 2016).

Hotel performance can be assessed on the basis of three categories of factors: physical characteristics, market and hotel managers' control (Tsai, Song \& Wong, 2009). The amount of resources available, the way of resource using and the efficiency of resource use are the main concerns in increasing the long-term hotel competitiveness.

Boateng et al, 2017 reveal a significant connection between service strategies and competitive advantage, emphasizing the need to reconsider the customer's central role and the need for customer satisfaction. The hotel services strategy must be focused on increasing the quality of services offered and improving the overall image of hotels, while it is necessary to apply tools, in order to measure the strategy performance.

Espino-Rodríguez, \& Pei Chun Lai, 2014 study the relationship between the competitive strategy and activity outsourcing, considering the asset specificity as the moderator variable. The results show that the activity outsourcing is positively correlated to the cost leadership strategy and negatively correlated to the differentiation strategy.

One of the most important factors which can influence to a great extent the hotel activity results is creating and using the competitive advantage. Thus, Espino-Rodríguez \& Ramírez-Fierro, (2017) analyze, based on a model, the relationship between the 
competitive advantage and the activity results, identifying a positive correlation between them, and a negative correlation between the competitive advantage and the degree of activity outsourcing, as well. The authors have shown that the intensity of the link between the competitive advantage and the performance of the hotels activity is higher in the case of the internal activities than in the case of the outsourced activities.

A number of studies consider innovation as an important element in increasing the competitiveness and performance of hotel business. Thus, Jacob et al, 2003 emphasize the positive role of innovative activity in improving the hotel image, in increasing the customer's satisfaction and profitability.

The relation between the strategy, competition and competitiveness has been analyzed by Ioncica et al., 2008. Thus, among the most important external determinants of hotel activity competitiveness, there were identified: the demand level and its changes, the competitive environment, the hotel location, the infrastructure, the legislative regulations in the field. The authors mention as internal factors of hotel activity competitiveness: the quality and diversity of services, the tariffs, promotion, the brand, and the innovation capacity.

\section{Methodology}

The analysis of hospitality performance in hotel units was carried out at two levels, from two perspectives:

- from the perspective of hotel units, based on macroeconomic data, collected from the TEMPO ONLINE data base of the National Institute of Statistics (Labor force, Tourism, Statistical Business Register);

- from the employees' perspective, based on microeconomic data obtained from a survey carried out on the employees from 4 and 5 star hotels in Bucharest.

The following statistical variables have been collected from the TEMPO ONLINE database, of the National Institute of Statistics: the number of hotel type accommodation establishments, accommodation capacity of hotel establishments, the average number of employees in hotels and restaurants, the turnover value of active enterprises in hospitality sector, variables which characterize the touristic activity in Romania, between 2009 and 2018.

The survey was conducted in January 2019 (by Aura Mihaela Voicu) on the basis of a questionnaire and included a random sample of 120 selected employees from those working in hotels with a high comfort category in Bucharest ( 4 and 5 stars). The questioning of the subjects and the collection of the responses were made through the online platform www.sondaje.ro.

The variables used in the analysis, the values of which were collected through the survey, were: (Table 1)

Table 1. Statistical variables included in the analysis

\begin{tabular}{|l|l|l|l|l|}
\hline $\begin{array}{l}\text { Name of the } \\
\text { variable }\end{array}$ & Notation & $\begin{array}{l}\text { Content of the } \\
\text { variable }\end{array}$ & $\begin{array}{l}\text { Type of the } \\
\text { variable }\end{array}$ & $\begin{array}{l}\text { Variants of the } \\
\text { variable (recoded) }\end{array}$ \\
\hline Education level & EDUCATION & $\begin{array}{l}\text { the level of the } \\
\text { last institution } \\
\text { graduated }\end{array}$ & $\begin{array}{l}\text { Ordinal variable, } \\
\text { with 3 response } \\
\text { categories: high } \\
\text { school, university } \\
\text { and postgraduate } \\
\text { studies }\end{array}$ & $\begin{array}{l}\text { education } \\
\text { 2= university } \\
\text { education } \\
3=\text { post-university } \\
\text { education }\end{array}$ \\
& & & & \\
\hline
\end{tabular}




\begin{tabular}{|c|c|c|c|c|}
\hline $\begin{array}{l}\text { Name of the } \\
\text { variable }\end{array}$ & Notation & $\begin{array}{l}\text { Content of the } \\
\text { variable }\end{array}$ & $\begin{array}{l}\text { Type of the } \\
\text { variable }\end{array}$ & $\begin{array}{l}\text { Variants of the } \\
\text { variable (recoded) }\end{array}$ \\
\hline $\begin{array}{l}\text { Experience in } \\
\text { hospitality } \\
\text { domain }\end{array}$ & EXPERIENCE_HOSP & $\begin{array}{l}\text { Number of years } \\
\text { of experience in } \\
\text { the hospitality } \\
\text { field }\end{array}$ & $\begin{array}{l}\text { Ordinal variable, } \\
\text { with } 3 \text { response } \\
\text { categories: less } \\
\text { than } 1 \text { year, } \\
\text { between } 1-5 \text { years } \\
\text { and more than } 5 \\
\text { years. }\end{array}$ & $\begin{array}{l}1=\text { low (less than } 1 \\
\text { year) } \\
2=\text { moderate (between } \\
1-5 \text { years) } \\
3=\text { high (more than } 5 \\
\text { years) }\end{array}$ \\
\hline Job type & JOB_TYPE & Job category & $\begin{array}{l}\text { Nominal variable } \\
\text { with } 16 \text { response } \\
\text { variants. }\end{array}$ & $\begin{array}{l}1=\text { leader position } \\
2=\text { execution position }\end{array}$ \\
\hline $\begin{array}{l}\text { Contribution to } \\
\text { activity } \\
\text { performance } \\
\text { and } \\
\text { competitiveness }\end{array}$ & CONTRIBUTION & $\begin{array}{l}\text { Employee's } \\
\text { perception of its } \\
\text { own contribution } \\
\text { to the } \\
\text { performance and } \\
\text { competitive } \\
\text { advantage of the } \\
\text { employing hotel, } \\
\text { measured by a } \\
\text { score of } 1 \text { to } 10 \text {. }\end{array}$ & $\begin{array}{l}\text { Ordinal variable, } \\
\text { with gradual scale } \\
\text { variants (1 = } \\
\text { minimum } \\
\text { contribution, } 10= \\
\text { maximum } \\
\text { contribution) }\end{array}$ & $\begin{array}{l}1=\text { very low } \\
\text { contribution (score 3- } \\
4 \text { ) } \\
2=\text { low contribution } \\
\text { (score 5) } \\
3=\text { medium } \\
\text { contribution (score 6- } \\
7 \text { ) } \\
4=\text { high contribution } \\
\text { (score 8) } \\
5=\text { very high } \\
\text { contribution (score 9- } \\
10 \text { ) }\end{array}$ \\
\hline
\end{tabular}

Source: authors' contribution, based on data collected by Aura Mihaela Voicu

The following objectives were formulated in the present paper:

1. the educational level determines significant differences regarding the employees' contribution in identifying a competitive advantage of the hotel in which they work.

2. the perception of luxury hotel employees about their own contribution to the performance and competitive advantage of the employing hotel unit is not significantly influenced by the job type;

3. employees' own perception of their personal contribution to achieving performance and competitiveness in the activity of the employing hotel unit is significantly influenced by their experience in hospitality domain.

The existence of a significant influence of the educational level of the employees and of the type of job on the perception of their own contribution to the achievement of a competitive advantage of the hotel in which they operate is tested by non-parametric tests for two or more independent samples: Kruskal-Wallis and Mann-Whitney U.

The relationship between the employees' experience in hospitality domain (the independent variable) and their own contribution to achieving performance and competitive advantage in the hotel activity (the dependent variable) has been analyzed with a proportional-odds cumulative ordinal regression model. The general form of the logit dependent variable is given by:

$\Omega_{j}=\operatorname{Prob}($ Score $\leq j) / \operatorname{Prob}($ Score $>j)=\operatorname{Prob}($ Score $\leq j) /(1-\operatorname{Prob}($ Score $\leq j)) ; j=\overline{1, r-1}$

(1)

where $r=5$ is the number of levels of the explained ordinal variable.

The logistic ordinal regression model has the following form: 


$$
\ln \left(\Omega_{j}\right)=\alpha_{j}+\beta \cdot \operatorname{EXPERIENCE}
$$

$\Omega_{j}$ is the ordinal explained variable, $\boldsymbol{\alpha}_{j}$ and $\boldsymbol{\beta}$ are the model parameters. $(j=\overline{1,4})$. The reference value of the explanatory variable is considered the third variant (high experience).

$$
\ln \left(\frac{\text { prob(Contribution_score } \leq j)}{1-\text { prob (Contribution_score } \leq j)}\right)=\boldsymbol{\alpha}_{j}+\boldsymbol{\beta} \cdot \boldsymbol{E X P E R I E N C E}
$$

After converting the logit value into probabilities, the model becomes:

$$
\operatorname{Prob}(\text { CONTRIBUTION })=\frac{e^{\alpha_{j}+\beta \cdot \text { EXPERIENCE }}}{1+e^{\alpha_{j}+\beta \cdot E X P E R I E N C E}}
$$

Applying the cumulative proportional odds logit model requires verification of the following assumptions: measuring the dependent variable on an ordinal scale; the categorical, ordinal or continuous numerical nature of the explanatory variable; the existence of proportional odds. Following the necessary tests, all hypotheses were validated.

\section{Results and discussions}

In Romania, according to the data provided by the National Institute of Statistics, there are 1616 hotel type - establishments of touristic reception (in 2018). Their number has risen steadily over the past 10 years, basically increasing by 1.39 times compared to 2009 . If in 2009 hotels with a high degree of comfort ( 4 and 5 stars) accounted for only $12 \%$ of the total number of hotels, in 2018 they reached almost 25\%, their share doubling during this time (Figure 1). Of these, a more pronounced dynamics recorded the 4-star hotels, which tripled their number (from 122 in 2009 to 359 in 2018). Luxury hotels (4 and 5 stars) existing in Romania have a capacity of about 60000 places, representing $30.67 \%$ of the total number of places in hotels (in 2018). In 2017, in CAEN section "Hotels and Restaurants", there were almost 170 thousand employees, 43\% more than in 2008. (Figure 2).

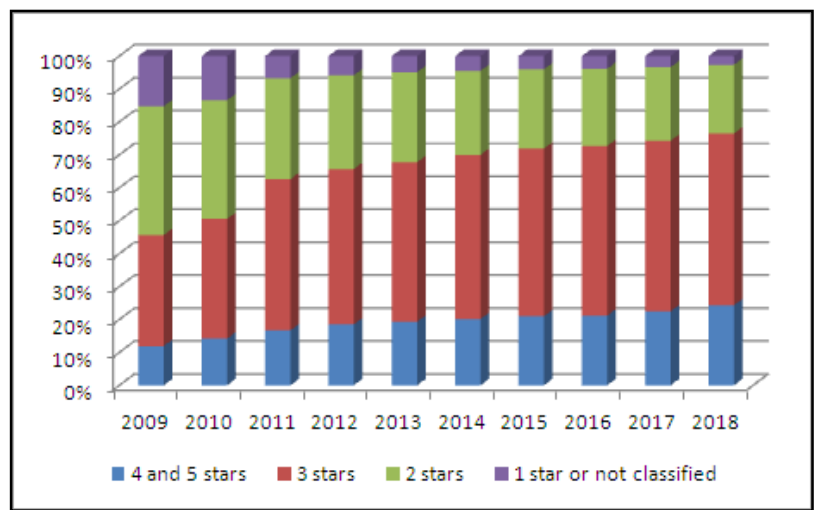

Figure 1. Number of hotels in Romania, by comfort category, 2009-2018 (\%)

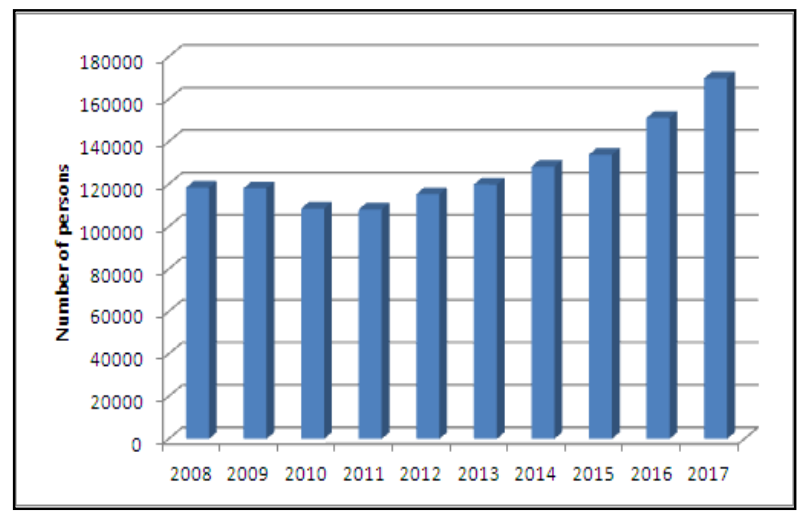

Figure 2. Average number of employees in Hotels and restaurants, in Romania, 2008-2017 (no. of persons)

Source: authors' processing, based on data provided by the National Institute of Statistics 
At the same time, the last 10 years were characterized by a doubling of arrivals of tourists accommodated in hotels, exceeding 9 million in 2018. Of these, $73.37 \%$ were Romanians, the rest were foreign tourists. Arrivals of tourists accommodated in luxury hotels ( 4 and 5 stars) recorded more than a tripling (they have increased 3.21 times in 2018. compared to 2009). If in 2009 more than half of the tourists' arrivals in 4 and 5 star hotels were foreign tourists (55.26\%), in 2018 their share reached 71.35\%. (Figure 3). At the same time, the turnover of active enterprises in hospitality sector increased from 4137.51 million lei in 2015 to 4890.93 million lei in 2017. (Figure 4).

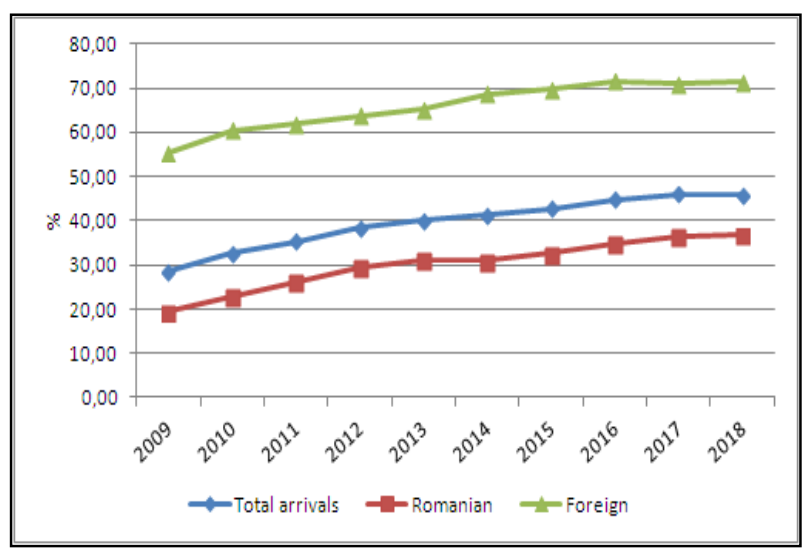

Figure 3. Arrivals of tourists accommodated in hotels, in Romania, by nationality, 2009-2018 (\%)

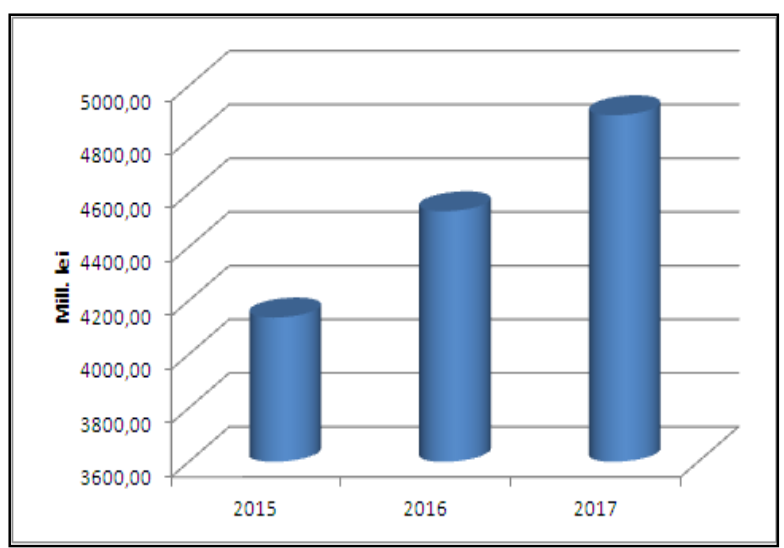

Figure 4. Turnover value in active enterprises in Hotels and similar accommodation, in Romania, 2015-2017 (mill. lei)

Source: authors' processing, based on data provided by the National Institute of Statistics

The relation between the ordinal variables: the level of graduate studies and the employees' perception of their contribution to achieving performance and competitive advantage in the hotels where they work was analyzed using the Kruskal-Wallis test for $k$ independent samples. The assumptions made were the following:

$H_{0}$ : the level of graduate studies does not lead to significant differences in the perception of employees' contribution to the creation of competitive advantage.

$H_{1}$ : there are significant differences between the perception level of the employees' contribution to the creation of the competitive advantage, depending on their education level.

The results of the analysis showed that for a minimum significance level of $0.04<0.05$ and a maximum probability of $96 \%$ the educational level determines a significant differentiation in how employees perceive their own contribution to creating a competitive advantage, as an important source in achieving a high performance of hotel business. (Tables 2 and 3)

Tables 2 and 3. The Kruskal-Wallis Test results

\begin{tabular}{|c|c|c|c|}
\hline \multicolumn{4}{|c|}{ Ranks } \\
\hline & Education & N & Mean Rank \\
\hline \multirow{4}{*}{ Contribution } & High school & 24 & 45,13 \\
& University & 75 & 65,06 \\
& Post university & 21 & 61,79 \\
& Total & 120 & \\
\hline
\end{tabular}

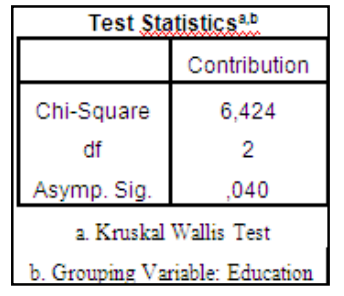

Source: Authors' own research. 
In order to test the influence of the job type on the employees' contribution to ensure the performance of the hotel activity, the following hypotheses were formulated:

$H_{0}$ : the job type does not lead to a significant differentiation of employees' perception of their contribution to achieving performance and competitive advantage in hotel activity

$H_{1}$ : the perception of the employees' contribution to the activity performance and to the creation of the hotel's competitive advantage differs significantly depending on the job type.

The results of the Mann-Whitney Test indicate that at a significance level of 0.22 $(>0.05)$, for a maximum probability of $78 \%$, there are not enough reasons for rejecting the null hypothesis, and as such it can be stated that employees with execution functions appreciate their own contribution to achieving the competitive advantage similar to the employees on management positions. (Tables 4 and 5)

Tables 4 and 5. The Mann-Whitney Test results

\begin{tabular}{|c|c|c|c|c|}
\hline & Rob_type & N & Mean Rank & Sum of Ranks \\
\hline \multirow{4}{*}{ Contribution } & Executive & 24 & 68,00 & 1632,00 \\
& Management & 96 & 58,63 & 5628,00 \\
& Total & 120 & & \\
\hline
\end{tabular}

\begin{tabular}{|c|c|}
\hline \multicolumn{2}{|c|}{ Test Statistics $^{\mathrm{a}}$} \\
\hline Contribution \\
\hline Mann-Whitney U & 972,000 \\
Wilcoxon W & 5628,000 \\
Z & $-1,221$ \\
Asymp. Sig. (2-tailed) &, 222 \\
\hline \multicolumn{2}{|c|}{ a. Grouping Variable: Job_type }
\end{tabular}

Source: Authors' own research

The dependence of the employees' contribution on achieving the performance and competitive advantage in hotel activity, on their experience in hospitality field is analyzed based on a logit regression model with cumulative probabilities, based on proportional odds. Chi-Square test results reflect that - at a significance level of less than 0.05 - the model with explanatory variables allows to improve the predictive capacity of the level of the explained variable compared to the model without regressors (Table 6)

Table 6. Model Fitting Information

\begin{tabular}{|l|r|r|r|l|}
\hline Model & -2 Log Likelihood & Chi-Square & df & Sig. \\
\hline Intercept Only & 150,199 & & & \\
Final & 27,922 & 122,278 & 2 &, 000 \\
\hline
\end{tabular}

Link function: Logit.

Source: Authors' own research

The results of the Pearson's Chi-Square Statistic confirm that the proposed model type is appropriate for the data set (minimum significance level: 0,706>0,05) (Table 7)

Table7. Goodness-of-Fit

\begin{tabular}{|l|r|r|r|}
\hline & Chi-Square & df & \multicolumn{1}{c|}{ Sig. } \\
\hline Pearson & 3,781 & 6 &, 706 \\
Deviance & 5,748 & 6 &, 452 \\
\hline
\end{tabular}

Link function: Logit.

Source: Authors' own research

The various forms of the coefficient of determination $R^{2}$ present quite large values, showing that the exogenous variable "Experience in hospitality domain" explains a high share 
of the variability in the endogenous variable "Employees' contribution to obtaining the competitive advantage" (63,9\%, respectively $66,7 \%)$ and so experience is a good predictor of this contribution. (Table 8)

Table 8. Pseudo R-Square Statistics

\begin{tabular}{|l|r|}
\hline Cox and Snell &, 639 \\
Nagelkerke &, 667 \\
McFadden &, 320 \\
\hline
\end{tabular}

Link function: Logit.

Source: Authors' own research

The applied model is based on the assumption of proportional odds existence, hypothesis tested with the Test of Parallel Lines. The minimum significance level of $0,452>0,05$ shows that there are no enough reasons to reject the null hypothesis, according to which the ordinal regression model with proportional odds has only one set of coefficients, for all the Intercept (Thresholds)-type values; the hypothesis of the existence of proportional odds is therefore validated (Table 9).

Table 9. Test of Parallel Linesa

\begin{tabular}{|l|r|r|r|r|}
\hline Model & -2 Log Likelihood & Chi-Square & df & \multicolumn{1}{c|}{ Sig. } \\
\hline $\begin{array}{l}\text { Null Hypothesis } \\
\text { General }\end{array}$ & 27,922 & & & \\
\hline
\end{tabular}

The null hypothesis states that the location parameters (slope coefficients) are the same across response categories.

a. Link function: Logit.

Source: Authors' own research

The model coefficients $\beta$ are statistically significant and positive, revealing a direct, positive association between the two variables (Table 10). The reference category of the explanatory variable is the one with the highest level ( $3=$ High Experience). Thus, the higher employees' experience categories in hospitality filed are associated with the perception of a higher contribution of employees to obtaining the competitive advantage, based on the following model:

\section{Low-experience/High-experience:}

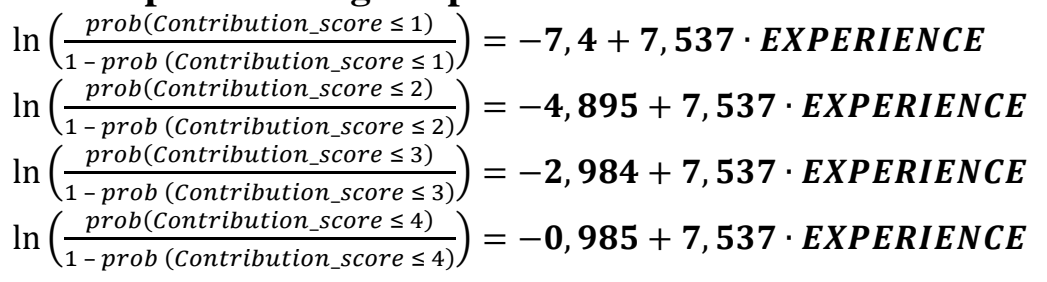

\section{Medium-experience/High-experience:}

$\ln \left(\frac{\text { prob }(\text { Contribution_score } \leq 1)}{1-\text { prob }(\text { Contribution_score } \leq 1)}\right)=-7,4+2,962 \cdot \boldsymbol{E X P E R I E N C E}$
$\ln \left(\frac{\text { prob }(\text { Contribution_score } \leq 2)}{1-\text { prob }(\text { Contribution_score } \leq 2)}\right)=-\mathbf{4 , 8 9 5}+2,962 \cdot \boldsymbol{E X P P E R I E N C E}$
$\ln \left(\frac{\text { prob }(\text { Contribution_score } \leq 3)}{1-\text { prob }(\text { Contribution_score } \leq 3)}\right)=-2,984+2,962 \cdot \boldsymbol{E X P E R I E N C E}$
$\ln \left(\frac{\text { prob }(\text { Contribution_score } \leq 4)}{1-\text { prob }(\text { Contribution_score } \leq 4)}\right)=-\mathbf{0 , 9 8 5}+2,962 \cdot \boldsymbol{E X P E R I E N C E}$ 
Table 10. Parameter Estimates

\begin{tabular}{|c|c|c|c|c|c|c|c|c|}
\hline & \multirow{2}{*}{$\begin{array}{c}\text { Estimat } \\
\mathrm{e}\end{array}$} & \multirow{2}{*}{$\begin{array}{l}\text { Std. } \\
\text { Error }\end{array}$} & \multirow[t]{2}{*}{ Wald } & \multirow[t]{2}{*}{$\mathrm{df}$} & \multirow{2}{*}{ Sig. } & \multicolumn{2}{|c|}{ 95\% Confidence Interval } \\
\hline & & & & & & & Lower Bound & Upper Bound \\
\hline \multirow{4}{*}{ Threshold } & {$[$ Contribution $=1]$} & $-7,400$ & ,877 & 71,217 & 1 & 000 & $-9,119$ & $-5,681$ \\
\hline & {$[$ Contribution $=2]$} & $-4,895$ & 664 & 54,403 & 1 & ,000 & $-6,195$ & $-3,594$ \\
\hline & {$[$ Contribution $=3]$} & $-2,984$ & ,582 & 26,251 & 1 & ,000 & $-4,126$ & $-1,843$ \\
\hline & $\begin{array}{l}{[\text { Contribution }=4]} \\
{[\text { Experience }=1]}\end{array}$ & $\begin{array}{r}-, 985 \\
7,537\end{array}$ & $\begin{array}{l}, 487 \\
, 903\end{array}$ & $\begin{array}{r}4,084 \\
69,726\end{array}$ & $\begin{array}{l}1 \\
1\end{array}$ & $\begin{array}{l}, 043 \\
, 000\end{array}$ & $\begin{array}{r}-1,940 \\
5,768\end{array}$ & $\begin{array}{r}-, 030 \\
9,307\end{array}$ \\
\hline Location & $\begin{array}{l}{[\text { Experience }=2]} \\
{[\text { Experience }=3]}\end{array}$ & $\begin{array}{r}2,962 \\
0^{\mathrm{a}}\end{array}$ & ,597 & 24,653 & $\begin{array}{l}1 \\
0\end{array}$ & ,000 & 1,793 & 4,131 \\
\hline
\end{tabular}

Link function: Logit.

a. This parameter is set to zero because it is redundant.

Source: Authors' own results

The results of the model parameter estimators analysis show that as the experience in hospitality field passes from "Low" category to "High" category, it is expected an average increase in the log-odds ratio that the score of the employees' contribution to the competitive advantage to grow (going from a lower category to a higher one) with 7.537 units (with a minimum of 5.768 and a maximum of 9.307 units). This means that the chances that the contribution score will increase are 1.88 times higher for low-experienced employees than for highly-experienced employees. At the same time, when the experience in the hospitality domain passes from "Moderate" category to "High" category, an average increase of 2.962 units in the log-odds ratio is expected to appear, (minimum 1.793 and maximum 4.131 units), as the contribution score changes from a lower category to a higher one. In other words, the chances for the contribution score to increase are 1.93 times higher for medium-experienced employees than for the highly-experienced ones.

Table11 Calculation of cumulative odds

\begin{tabular}{|c|c|c|c|c|c|}
\hline Experience category & \multicolumn{5}{|c|}{ Contribution score } \\
\hline High experience & 1 & 2 & 3 & 4 & 5 \\
\hline Cumulative logit & & $-7,4000$ & $-4,8950$ & $-2,9840$ & $-0,9850$ \\
\hline Cumulative odds & & 0,0006 & 0,0075 & 0,0506 & 0,3734 \\
\hline Cumulative proportion & 1 & 0,9994 & 0,9926 & 0,9518 & 0,7281 \\
\hline Category probability & 0,0006 & 0,0068 & 0,0407 & 0,2237 & 0,7281 \\
\hline Moderate experience & 1 & 2 & 3 & 4 & 5 \\
\hline Cumulative logit & & $-4,4380$ & $-1,9330$ & $-0,0220$ & 1,9770 \\
\hline Cumulative odds & & 0,0118 & 0,1447 & 0,9782 & 7,2210 \\
\hline Cumulative proportion & 1 & 0,9883 & 0,8736 & 0,5055 & 0,1216 \\
\hline Category probability & 0,0117 & 0,1147 & 0,3681 & 0,3839 & 0,1216 \\
\hline Low experience & 1 & 2 & 3 & 4 & 5 \\
\hline Cumulative logit & & 0,1370 & 2,6420 & 4,5530 & 6,5520 \\
\hline Cumulative odds & & 1,1468 & 14,0413 & 94,9167 & 700,6441 \\
\hline Cumulative proportion & 1 & 0,4658 & 0,0665 & 0,0104 & 0,0014 \\
\hline Category probability & 0,5342 & 0,3993 & 0,0561 & 0,0090 & 0,0014 \\
\hline Odds ratio & 1 & 2 & 3 & 4 & 5 \\
\hline Low/High exp. & - & 1,88 & 1,88 & 1,88 & 1,88 \\
\hline Moderate/High exp. & - & 1,93 & 1,93 & 1,93 & 1,93 \\
\hline
\end{tabular}


The average estimated probability for low-experienced employees to have a contribution on obtaining activity performance and competitive advantage ranges between 0,14\% (for very high contribution) and 53,43\% (for very low contribution). Moderately experienced employees are assigned an average estimated probability to have a contribution in obtaining performance and competitive advantage that ranges from 1,17\% (for very low contribution) to 38,39\% (for high contribution). The average estimated probability for highly-experienced employees to have a contribution on obtaining performance and competitive advantage varies from $0,06 \%$ (for very low contribution) to $72,81 \%$ (for a very high contribution) (Table 11).

Table no. 12 summarizes the results on the likelihood that employees' contribution to achieving competitive advantage and performance will be included in each of the five categories, depending on the employees' experience in hospitality domain.

Table12. Estimated probabilities by employees' contribution category, in obtaining competitive advantage

\begin{tabular}{|l|l|r|r|r|r|r|}
\hline \multirow{2}{*}{} & \multicolumn{6}{|c|}{ Extimated cell probability for Response category } \\
(contribution)
\end{tabular}

Source: Authors' own results

Within each category of experience, there is no variation in the likelihood that the perception of the employees' contribution to the competitive advantage is framed at each level (very low, low, moderate, high and very high), so the standard deviations of the probabilities are 0 . At the sample level, the estimated average probability varies between $15.49 \%$ (for moderate contribution) and $28.37 \%$ (for the very high contribution).

\section{Conclusion}

The hotel industry is an important driver in tourism development of a region, with positive effects on economic growth, concentrating to a large extent the regional tourism services. The quality of services in this sector is decisive for improving the hotel activity performance, especially in terms of a competitive environment increasingly well defined. The service quality is directly proportional to the hotel comfort category. In 2018 Romania had 34 fivestar hotels and 359 four-star hotels, representing less than a quarter of all hotels (24.32\%), twice the number of hotels of this kind in 2009. 
Analyzing the main determinants of the employees' contribution to obtaining the competitive advantage in hotel activity, there were considered, among other variables, the employees' education level, job type and work experience in hospitality domain. Thus, the results revealed that the level of education determines a significant differentiation in how employees perceive their own contribution to creating a competitive advantage, as an important source in achieving a high performance of hotel business. Also, the employees with executive functions appreciate their own contribution to obtaining the competitive advantage similar to the employees with management positions. The average estimated probability for low-experienced employees to have a contribution on obtaining activity performance and competitive advantage ranges between $0,14 \%$ (for very high contribution) and 53,43\% (for very low contribution). Moderately experienced employees are assigned an average estimated probability to have a contribution in obtaining performance and competitive advantage that ranges from $1,17 \%$ (for very low contribution) to 38,39\% (for high contribution). The average estimated probability for highly-experienced employees to have a contribution on obtaining performance and competitive advantage varies from $0,06 \%$ (for very low contribution) to $72,81 \%$ (for a very high contribution). The results obtained are useful in identifying and characterizing how the employees in luxury hotel industry appreciate their own contribution to ensuring the performance of their work and analyzing the main determinants that underpin this personal perception.

\section{References}

Andriessen, D. (2006). On the metaphorical nature of intellectual capital: a textual analysis. Journal of Intellectual Capital, 7(1), 93-110.

Aldag, R.J., \& Stearns, T.M. (1991). Management (2nd ed.). Cincinnati, OH: South-Western Publishing.

Barnes, B.R., Leonidou, L.C., Siu, N.Y.M., \& Leonidou, C. (2010). Opportunism as the inhibiting trigger for developing long-term-oriented Western exporter - Hong Kong importer relationships. Journal of International Marketing, 18(2), 35-64.

Barroso, J.M.D. (2013). Speech by President Barroso on the outcome of the European Council meeting on the Multiannual Financial Framework of 7-8 February 2013. Retrieved from http://europa.eu/rapid/press-release_SPEECH-13-130_en.htm. -

Bratianu, C. (2011a). Changing paradigm for knowledge metaphors from dynamics to thermodynamics. System Research and Behavioral Science, 28, 160-169.

Bratianu, C. (2011b). A new perspective of the intellectual capital dynamics in organizations. In Vallejo-Alonso, B., Rodriguez-Castellanos, A., Arregui-Ayastuy, G. (Eds.). Identifying, measuring, and valuing knowledge-based intangible assets: new perspectives (pp. 1-21). Hershey, PA: IGI Global.

Bratianu, C. (2013). The triple helix of the organizational knowledge. Management Dynamics in the Knowledge Economy, 1(2013), 207-220.

Ernst \& Young (2011). The sustainability revolution. Excellence in sustainability reporting awards 2011. Retrieved from http://www.ey.com/ZA/en/Services/SpecialtyServices/Climate-Change- and-Sustainability-Services/2011---ESR---Main-Page.

Nonaka, I., \& Takeuchi, H. (1995). The knowledge-creating company. How Japanese companies create the dynamics of innovation. Oxford: Oxford University Press. 